Portland State University

PDXScholar

\title{
A study of prospective entrepreneurs' perceptions of knowledge required for success : and its implications for curriculum development and revision
}

Vickie Lynn Schray

Portland State University

Follow this and additional works at: https://pdxscholar.library.pdx.edu/open_access_etds

Part of the Business Commons, and the Education Commons

Let us know how access to this document benefits you.

\section{Recommended Citation}

Schray, Vickie Lynn, "A study of prospective entrepreneurs' perceptions of knowledge required for success : and its implications for curriculum development and revision" (1990). Dissertations and Theses. Paper 4146.

https://doi.org/10.15760/etd.6030

This Thesis is brought to you for free and open access. It has been accepted for inclusion in Dissertations and Theses by an authorized administrator of PDXScholar. Please contact us if we can make this document more accessible: pdxscholar@pdx.edu. 
AN ABSTRACT OF THE THESIS OF Vickie Lynn Schray for the Masters of Science in Teaching presented May 15, 1990. Title: A study of Prospective Entrepreneurs' Perceptions of Knowledge Required For Success: And Its Implications for Curriculum Development and Revision.

APPROVED BY THE MEMBERS OF THE THESIS COMMITTEE:
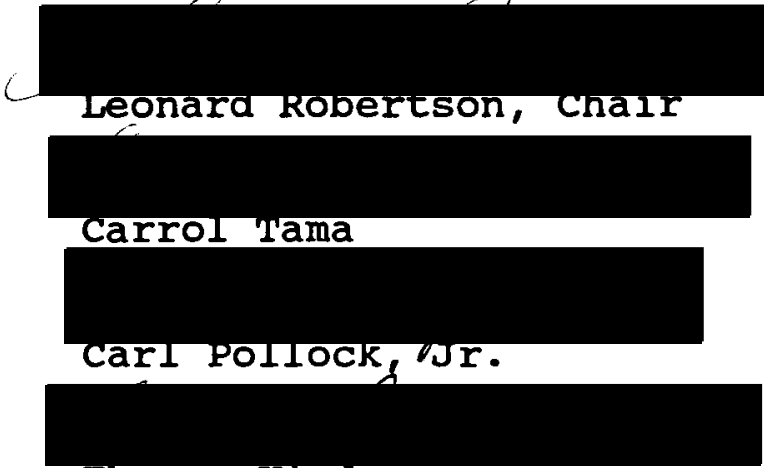

Thomas Kindermann

The purpose of this study was to provide information to secondary, post-secondary and vocational teachers on what instructional areas should be taught to prospective entrepreneurs involved in pre-venture training. In addition it was hoped that information gained from the study would add to the existing body of knowledge on entrepreneurship education and validate entrepreneurship education practices in Oregon.

The study was designed to obtain the opinions of prospective entrepreneurs on what knowledge they deemed to be most critical to small business success. 
The study was conducted through the Portland and Clackamas offices of the Small Business Development Centers, and involved 89 students enrolled in the "starting Your Own Business" courses and Greenhouse programs. The students were surveyed using questionnaires which were designed and validated through the course of the study.

Data collected for this study were analyzed by descriptive and inferential statistics with the dependent variable, the perceived importance to small business success, to determine what instructional topics should be included in entrepreneurship education curriculum. Analysis of variance was completed among four multi-variate subgroups, a) race, b) marital status, c)age and d)highest educational level attained.

The results of this study demonstrate that the results are consistent across sub-groups of age, educational level, sex, and marital status. Significant differences were found for the factor "race." It should not be inferred that races differ in response to the knowldege needed for small business success, as the samples size of ethnic minorities was small.

Significant differences were found on individual subtopics between the groups differing on whether there was Prior Small Business Ownership or not, and also between the groups differing Family Entrepreneurial Background. We can infer that all of the above sub-groups perceive the 
entrepreneurial activities listed on the questionnaire as important to small business success, and should be included in entrepreneurship education curriculum.

A $t$-test was completed on a number of comparison variables; a) sex, b) prior business ownership, and c) family entrepreneurial background. Statistical significance of $p>=.05$ was required to reject the null hypotheses.

Although the percentage of female respondents 31 (58.5\%) exceeded the average percentage of female entrepreneurs (51\%) identified in prior research there were no significant differences found between the responses of males and females in this study.

The demographic profile of the respondents supported prior research in the area on entrepreneurship. The number of females, educational achievement level, prior business ownership and family entrepreneurial history met or exceeded the averages found in prior studies completed nationwide.

Significant differences were found between the responses of the subjects who a) had a family history of entrepreneurial ventures and those who had not, were found on the Managing Finances and Advertising Plan, and b) had Prior Small Business Ownership and those who had not on the Managing Finances topic.

Although the sample for this study was small, the demographic profile of the respondents was similar to larger samples established in prior research efforts. 
The findings of the questionnaire data that all topics included in the instrument are perceived by the prospective entrepreneurs in this study to be important to small business success will provide a basis for future entrepreneurship education curriculum development in oregon. 
A STUDY OF PROSPECTIVE ENTREPRENEURS' PERCEPTIONS OF KNOWLEDGE REQUIRED FOR SUCCESS: AND ITS IMPLICATIONS FOR CURRICULUM DEVELOPMENT AND REVISION

by

VICKIE LYNN SCHRAY

A thesis submitted in partial fulfillment of the requirements for the degree

\author{
MASTERS OF SCIENCE IN TEACHING \\ in \\ BUSINESS EDUCATION
}

Portland State University

1990 
TO THE OFFICE OF GRADUATE STUDIES:

The members of the committee approve the thesis of Vickie Lynn Schray presented May 15, 1990.

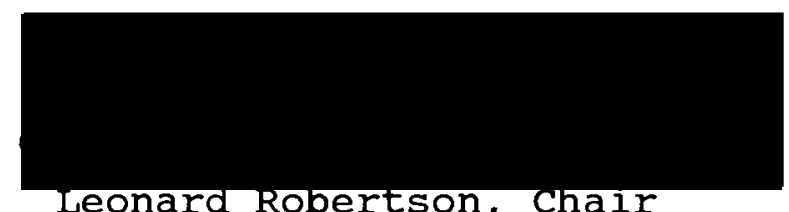

Leonard Robertson, Chair

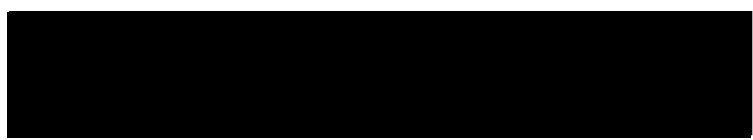

Carrol Tama

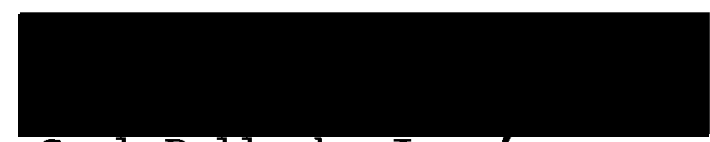

Carl Pollock, Jr.

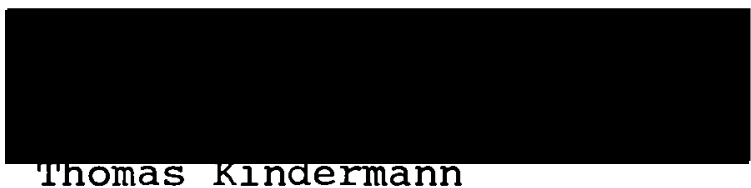

Thomas Klndermann

\section{APPROVED:}

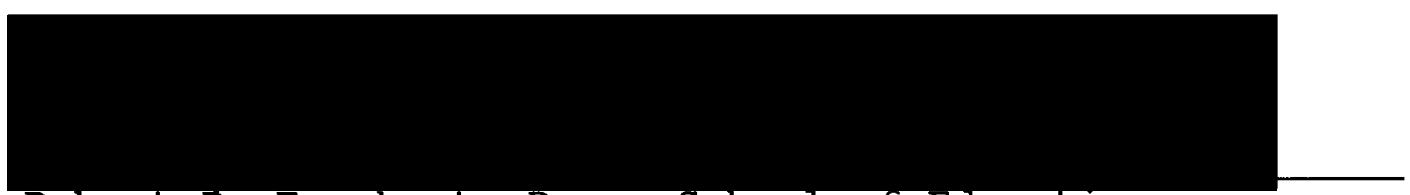

Robert B. Everhart, Dean, School of Education

C. William Savery, Interim vice provost for Graduate studies and Research 


\section{ACKNOWLEDGEMENTS}

The completion of this study marks a number of important events in my life, the birth of my two children, the founding of my own small business, and my 30th birthday. My deepest appreciation to all those who provided support, assistance and encouragement.

Dr. Leonard Robertson, my Masters Degree Advisor, who continually "advised" and "revised" throughout the development and completion of this project. His knowledge and assistance in content revision, statistical analysis, and moral support were invaluable.

To my parents Darrell and Sandy, who encouraged me to be the first in our family to attend college. Their continued support and babysitting enabled me to complete my graduate degree and much more.

Nicole and Ryan, whose existence may have lengthened the time it took to complete this study, but whose addition to my life made the project more pleasurable and meaningful.

To my husband Paul, who financially and emotionally supported me throughout the length of this program of study, to his intangible and tangible efforts to assist me I am eternally grateful. 
TABLE OF CONTENTS

ACKNOWLEDGEMENTS ...................... ii

LIST OF TABLES...................... vi

CHAPTER

I INTRODUCTION.................... I

Statement of the Problem............ 4

Purpose of the study................ 5

Need for the study................. 5

Limitations................... 6

Definition of Terms............... 6

II REVIEW OF LITERATURE................ 8

Introduction.................. 8

Overview of Entrepreneurship Education..... 9

Characteristics of the Entrepreneur....... 18

Small Business-Success or Failure........ 22

Summary........................ 25

III METHODS AND PROCEDURES............... 28

Instrument Design............... 28

Selection of The subjects............ 32

Methodology ..................... 33

Data Analysis.................... 34

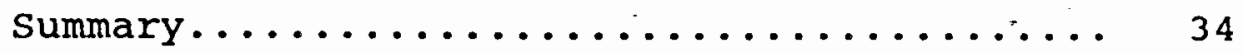

IV $\quad$ FINDINGS $\ldots \ldots \ldots \ldots \ldots \ldots \ldots \ldots \ldots \ldots \ldots \ldots \ldots \ldots \ldots$ 
Presentation of Demographic Data........ 37

Presentation of Questionaire Data........ 39

summary....................... 43

VI CONCLUSIONS AND RECOMMENDATIONS.......... 45

Conclusions...................... 45

Acceptance of Null Hypotheses.......... 48

Recommendations for Further study........ 49

summary ........................ 50

REFERENCES.......................... 52

APPENDICES

A Cover Letter.................... 55

B Demographic Data Sheet.............. 57

C Questionnaire..................... 59

D Frequency of Responses............... 62 


\section{LIST OF TABLES}

TABLE

PAGE

I Response Rate.................. 36

II Age of Respondents.............. 38

III Educational Level Attained By Respondents................... 38

IV Ranking of the Mean Scores of the Sections Across Response............ 41

$V$ Significant Differences In Variable of Perceived Importance Between Sub-Groups. 43

VI Comparison Between Demographic Percentage of This study to Prior Findings........48 
CHAPTER I

\section{INTRODUCTION}

The eighties have seen a resurgence of the entrepreneurial spirit. Not since pre-industrial times has there been such an interest in self employment.

Thomas L. Powers (1982 pp. 30-31) describes the business environment of today as the "post-industrial era" he added:

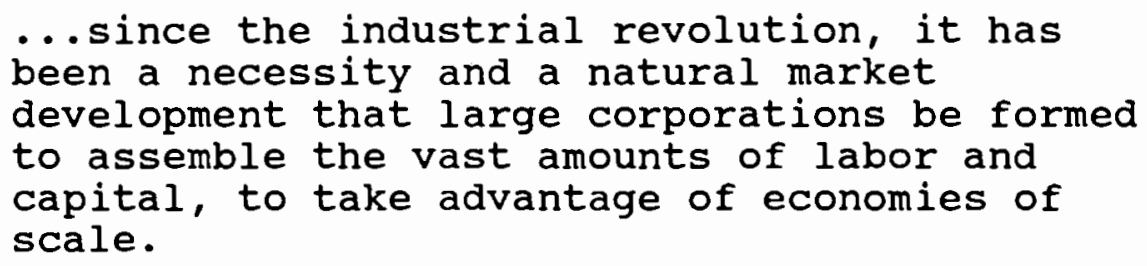

Today's business environment is very complex and dynamic. The smaller firms can more readily change and adapt to the constantly changing environment.

John Naisbett, author of Megatrends, stated that "our economy is moving into a post industrial stage; one characteristic of this new type of economy is the presence of more small businesses who will be responsible for the development of new products and services."

New business incorporations recorded by Dunn and Bradstreet rose to over 668,000 in 1985 up 5.3\% from the previous year, and sole proprietorships filed with the 
Internal Revenue Service reached 10.9 million in 1984.

The White House Commission on Small Business Report (1980), stated that the large number of businesses, over 15 million, that have begun during the last few years "represents a renaissance among Americans of self confidence and risk taking."

Sylvia Porter's Guide for Entrepreneurs (p. 31) listed four major factors which have created this "golden age." WIDE SPREAD OPPORTUNITY - new technologies, growing emphasis on service industries, and consumers with enough disposable income to satisfy their individual tastes.

FAVORABLE FINANCIAL CLIMATE - rarely has money flowed so freely, venture capital is available to many entrepreneurs and a two pay-check household; now common among household allows one spouse the freedom to experiment.

SUPPORT SERVICES - Universities offer special courses, consultants sell advice, and bookstores are filled with small business self help books.

STATUS - admiration for the entrepreneur has risen to fever pitch. Such social acceptance, even in failure, eases the risk.

It would seem, after reading the data available on the number of new small business ventures, that there is room for all who have the drive and the desire to become an entrepreneur. Unfortunately, success in not guaranteed to all who start a small business. In 1985, an estimated 57,000 new businesses failed. The most frequently cited cause of small business failure has been poor or nonexistent management skills (Peterson \& Album 1984). 
The state of Sma11 Business: A Report to the President

(U.S. Small Business Administration 1984) indicated that small firms contribute approximately $38 \%$ of the nations Gross National Product, and employ $48 \%$ of the private work force. As a result of this significant contribution of goods, services and employment to the G.N.P., the private sector and government have realized that small business is a vital segment of our economy.

This new realization coupled with the high rate of failure among new business has made the nation as well as the small business owner realize that there is a real and immediate need for entrepreneurial training.

When defining the entrepreneur, most people immediately think of a person willing to take a risk. Although it may be difficult to teach risk taking, it is possible to teach people the knowledge needed to minimize the risks (zelinko 1983) •

It was Zelinko's assumption, that prompted me to undertake further study of the knowledge needed by entrepreneurs to enhance their business success.

As a vocational educator and a small business owner, I felt a need to take a more practical and basic look into what enhances the success of the entrepreneur. In my review of literature, I came across the following conclusion taken from the National Task Force on Education and Training for Minority Business Enterprises, Task Force Report (1974): 
...after two years of deliberations and hearings, the National Task Force on Education and Training for Minority Business Enterprises concluded that the primary cause of business failure is a lack of business and management skills.

Although the report is dated, the conclusions were not a statement of how things were, but how they could and should be. There is no question that most businesses fail due to the lack of training and knowledge.

STATEMENT OF THE PROBLEM

This study was designed to gather ratings of topics taught in entrepreneurial training courses from prospective entrepreneurs engaged in pre-venture training for three reasons:

1. To determine the importance prospective entrepreneurs ascribe to selected topics taught in entrepreneurial training.

2. To provide a ranking of the selected topics taught in entrepreneurial training.

3. To determine if various sub-groups rate the topics differently.

The following central hypotheses were analyzed:

1. The study group will perceive the topics to be important in entrepreneurial training.

2. The ranking of topics will support their use in entrepreneurial training.

3. There will be no statistically significant differences in the dependent variable, mean scores of the topics, when groups are analyzed by the following independents variables:
a. $\operatorname{sex}$
b. educational levels
c. prior small business ownership 
d. age
e. race
f. family entrepreneurial history

PURPOSE OF THE STUDY

The major purpose of this study was to provide information on which instructional areas should be taught to prospective entrepreneurs engaged in pre-venture training, as identified by the prospective entrepreneurs themselves.

Small business owners, secondary, and post-secondary vocational teachers may find this information helpful in the revision of current entrepreneurship training or in the development of new entrepreneurship curriculum.

The secondary purpose was to add to the existing body of knowledge on entrepreneurship education.

NEED FOR THE STUDY

A number of factors contributed to the assumption that a need for the study existed. First, as a vocational educator at the secondary level who is responsible for the career development programs at all levels of instruction in Wilson High School and its feeder schools, I observed that entrepreneurship as a viable career option was all but ignored. Second, at the time that I elected to begin my thesis I also started my own small business. Finally, Portland Public Schools applied for and received federal grant money through the Workforce 2000 program to develop 
new curriculum for a Small Business Ownership class at wilson High School, which I was elected to teach. Furthermore, as entrepreneurship has been the backbone of oregon's economic recovery it became apparent that a need existed to gather data that would identify important entrepreneurship educational topics that would assist in the development of new entrepreneurship curriculum.

No effort was made to identify new knowledge in the field of entrepreneurship, but rather to confirm prior research in entrepreneurship education for use in curriculum development.

\section{LIMITATIONS}

Subjects in the study were enrolled in entrepreneurial training courses provided by the Small Business Development Center (SBDC) through Portland and clackamas Community College. Therefore, the sample is not representative of all those entrepreneurs who initiate a small business venture.

The results of the study may not be generalized to all those who have taken courses through the SBDC network, as only those student enrolled in the Portland and clackamas Small Business Ownership classes participated in the study.

\section{DEFINITION OF TERMS}

Entrepreneur: the United States Department of Education 
Task Force for Entrepreneurship Education (1984) has defined the entrepreneur as "...an individual who undertakes selfdirected initiatives and assumes personal risks in creating and operating a profit oriented business."

Small Business: for the purpose of this study a small business is defined as having 20 or fewer employees and having been in business five years. SBA: U.S. Small Business Administration, an independent federal agency created by Congress in 1953, to aid small business owners and managers.

SBDC: Small Business Development Centers, a U.S. program aimed at providing a diverse range of advice to small business people through the community college network. The program is a result of the SBDC Act of 1979 .

\section{SUMMARY}

The significant contributions of small business to the continued economic growth of the nation, coupled with the high rate of small business failure indicates that a need for entrepreneurial education exists.

The question this study hoped to answer was what knowledge do prospective entrepreneur' perceive to be the most important to small business success? 
CHAPTER II

REVIEW OF LITERATURE

During the initial research for this study the journals of Frontiers for Entrepreneurial Research, (Frontiers) and more specifically The Center for Entrepreneurial studies at Babson College, Wellesly, Massachusetts was frequently cited. After contacting Babson college to determine the availability of the "Frontiers" I was referred to Dick Sears, the Director of the Center For Entrepreneurial Ventures in Beaverton, oregon. The center at that time was a member of the SBDC network. The library at the center for Entreprneurial Venture had the entire set of "Frontiers" and allowed me to borrow them for an extended period of time. This comprehensive resource allowed me to review the majority of research completed on the topic of entrepreneurship between 1981-87. Furthermore, the analysis of the 227 studies published in the volumes provide research guidelines for this study.

INTRODUCTION

Among the private sector, government, and most recently, educators, "entrepreneur" and "entrepreneurship" have emerged as the buzz words of the eighties. 
As a result, more research has been done in the area of small business ownership in the past five years than in the previous thirty (Greenwood et. al. 1984).

The mass of research has done more to confuse than to clarify who and what the entrepreneur is. Rather than replicating previous studies, researchers have looked at many factors, in search of the elusive key to entrepreneurial success.

Sexton (1982 p. 408) concluded that the major difficulty in the study of entrepreneurship is that;

...there is a need for a definition of entrepreneurship which would accommodate measurement, comparison and performance results. Until that time the definition should be clearly stated in each research effort.

With the vast amount of literature available and the diverse topics included under the heading of entrepreneurship, I have elected to organize my review in the following manner:

1. Overview of Entrepreneurship Education

2. Characteristics of the Entrepreneur

3. Small Business: Success or Failure OVERVIEW OF ENTREPRENEURSHIP EDUCATION Entrepreneurship has received a great deal of attention by the public sector and government in recent years. Gumpert (1984) listed the following as key reasons: 
The disproportionate number of new jobs generated by small firms.

The disproportionate number of new inventions and innovations created by individual inventors and independent enterprises.

The opportunities for minorities and women.

The symbolism of the best of America, eg., rugged individualism, the pioneering spirit, free enterprise.

Entrepreneurship is many things to many people. Professor Jeffery Timmons' definition of entrepreneurship in New Venture Creation: A Guide to Small Business Development states that "entrepreneurship is the process of planning and organizing a small business venture: the marshalling of people and resources to create, develop and implement solutions to problems to meet peoples' needs" (p. 4). In defining the entrepreneur and entrepreneurship, Kent (1984 p. 4) described him/her as: "more than selfemployed. Those who start businesses solely as an alternative to wage employment do not participate in the entrepreneurial event. Entrepreneurship requires an element of growth that leads to innovation, job creation, and economic expansion."

Bailey (1985 p. 7) in his study of the learning styles of successful entrepreneurs, postulated that "the act of making the business is the entrepreneurial act: that is the act of perceiving an opportunity, assessing and risking resources to exploit the opportunity, and the managing of 
the process of building a venture from an idea."

Argument exists over the point at which the

individual ceases to be an entrepreneur. It has been argued that at the point when the business begins to operate at an acceptable level of performance, the entrepreneur becomes an owner/manager (Bailey 1985).

Bailey defined the entrepreneur as "the person who carries out the act of making a business." He added that the "individual will remain an entreprenuer as long as there exists a degree of risk in his strategic decision making" (pp. 8-9) .

The first definition available on the function of the entrepreneur as a risk taker, was given by Richard Cantillion (1755). In addition, he is the person responsible for the term entrepreneur. In comparison, Schumpter (1934) saw the entrepreneur primarily as an innovator and not a risk taker.

President Reagan in a proclamation designating May 18-24, 1986 as National Small Business Week expressed the feelings of our society in regards to the entrepreneur:

The business of America begins with small business...millions of men and women bold and imaginative, self starters, seizing opportunities and providing the jobs that help to ensure that our nation will remain economically strong and free.

Nothing characterizes the American economy better than our 14 million small businesses. They should be a source of pride for all Americans. Collins and Moore (1970) refer to the entrepreneur 
as the "Organization Maker" he/she was described as follows:

The independent entrepreneur

(businessman), building the organization from scratch must typically find support on an opportunistic and not well planned basis. Furthermore, he cannot retrieve his errors by appeal to a sponsoring system. The new organization survival is often the driving force of the independent entreprenuer.

While searching for a definitive description of "the entrepreneur," researchers have uncovered many different types of entrepreneurs. There is no agreement on the definition of what an entrepreneur is, or even at what point one stops being an entrepreneur.

The difference between the internal and independent entreprenuer, as identified by Shils and zucker (1979), is their different philosphies on risk. The internal entrepreneur sees risk at the career level, whereas the independent entrepreneurs see risk as being financial or psychological.

Three types of entrepreneurs were identified by Knight (1983 pp. 9-14) the craft inventor who develops and improves the product; the promoter who has strong marketing and sales skills and who concentrates on founding a new business by taking advantage of a new discovery or idea; and the general manager, a coordinator who will seek expertise from the outside.

In the literature one definition for entrepreneurship seems to be used more than any other, 
although this too appears to be used infrequently. This was the definition established by the United states Department of Education Task Force for Entrepreneurship Education (1984):
"the entrepreneur is an individual who undertakes self directed initiatives and assumes personal risks in creating and operating a profit oriented business."
It is this definition that I elected to use for the study.

Since the primary purpose of this research effort was to provide a basis for curriculum development and revision, it was necessary to provide a background of the development of entrepreneurship education.

Until the end of the 1970's entrepreneurship education was all but ignored. As a result of economic recession and the increase in unemployment, the attitude towards the importance of pre-venture preparation changed (Chrisman 1984).

The U.S. Small Business Administration, created by Congress in 1953 as an independent federal agency, has been in the forefront of entrepreneurship assistance. The SBA offers counseling, training, and publications to educate prospective and present adult small business owners and managers (Perrin 1983).

In 1977 the SBA established the first Small Business Development Centers. The success of the original seven programs prompted the SBA and congress to expand the 
program nationwide. The purpose of the SBDC was aptly given in the "Program Annnouncement, Small Business Development Center" (U.S. SBA 1984)

The Small Business Development Center Program focuses on providing in-depth quality assistance to small business in all areas which promote growth, expansion, innovation, increased productivity and management improvement. SBDC... concentrate on developing the unique resources of the University System, the private sector, and state and local governments to provide services to the small business community which are not available elsewhere.

In comparison to the attitude towards

entrepreneurship education during the 70's, the $80^{\prime} \mathrm{s}$ have been the decade in which the nation worked towards a common goal: to help the small business entrepreneur develop. In 1980 the White House Conference on Small Business convened in Washington D.C. Of those small business owners who were represented, the major concern voiced was the lack of a systematic national program of entrepreneurship education.

A recommendation from the white House Commission Small Business, "America's Small Business Economy-Agenda for Action" (1980) stated:

A national policy should be established for the support of entrepreneurial education and training, continuing education, and management assistance provided by the public and private sector as an opportunity for every American who wishes to own his or her own business and should receive recognition as a priority from the highest levels of government. 
In 1981, Dr. Robert M. Worthington, the Assistant Secretary for Vocational and Adult Education of the U.S. Department of Education, authorized the formation of the U.S. Department of Education Task Force for Entrepreneurship Education. The Task force was organized to assume the national leadership for the promotion and expansion of entrepreneurship education and training for vocational and adult education.

The U.S. Department of Vocational and Adult Education held a "Symposium on Entrepreneurship Education." The panel of experts who were invited to participate generated many ideas that were used to develop a policy statement for the U.S. Department of Education (Ross 1984).

In the fall of 1983 the U.S. Department of Education released the official policy statement on entrepreneurship education. The document defined entrepreneurship education as taking many forms:

... (1) young people in school who are considering small business ownership as a career option, andtherefore, considered future entrepreneurs; (2) persons who are potential entrepreneurs and are ready to become self-employed; (3) those who are currently operating a small business; and (4) those whose work is or will be associated with the small business sector.

In addition, the U.S. Department of Education (Workplace Education 1984) stated that its policy would be to: 
part of vocational and adult education, and to support all endeavors which serve to increase the capacity of vocational and adult education to deliver education for entrepreneurship.

A study of "New Developments in Entrepreneurship Education" (Vesper 1984 P. 490) showed that over 245 schools of higher education now offer programs in entrepreneurship education. This number is a dramatic increase over the 85 programs offered a decade earlier.

Many variations in instructional techniques have emerged, such as the development of marketing, management and finance courses aimed specifically at entrepreneurial ventures. Other variations include, the introduction of entrepreneurship into other existing courses, and the use of an entrepreneurship course as a "capstone" course (Vesper 1984 P. 493).

Within these various courses, a number of interesting approaches emerged. For example, the University of Nevada requires the development of prototypes, not just a paper design as part of the course, and Marquette University has adopted a grading policy under which any student who is able to raise $\$ 10,000$ or more on the basis of a venture plan developed in the class receives an automatic "A" (Vesper 1984).

The focus of entrepreneurship education is changing from assisting existing small businesses to preparing new entrepreneurs. Debate currently exists over at what age the 
preparation of new and potential entrepreneurs is appropriate? Many educators feel that the study of entrepreneurship as a career option should begin at the elementary level, and continue at all phases of learning levels and settings (steward 1985). In contrast Hook (1987) states that; "... a potentially disturbing situation seems to be developing: entrepreneurial education seems to be moving down to the secondary level." Hook's major point of contention is that "... technical aspects of business formation and operation may be inappropriate at the secondary level."

Kent (1983) identifed three levels at which entrepreneurship education should take place:

1. the sensitization of potential entrepreneurs to the economic contribution of the entrepreneur and its viability as a career option (primary school)

2. inspire and convince the potential entrepreneur of the viability of possessing his own business (early in secondary school)

3. the acquisition of the motivation and skills necessary to initiate and develop a new enterprise (late in secondary school)

PACE was developed by M. Catherine Ashmore and Sandra Pritz (1983), nationally recognized experts in the field of entrepreneurship education. The development of PACE the product was sponsored by the U.S. Department of Education, Office of Vocational and Adult Education, and incorporated the competencies for creating and operating a small business in eighteen modules. 
PACE is a competency based individualized program which was designed to teach current and future entrepreneurs how to establish and manage their own business. The 18 modules contained in PACE were written on three levels: 1) awareness, 2) exploration and creativity and 3) preparation and problem solving (Genetta 1984).

\section{CHARACTERISTICS OF THE ENTREPRENEUR}

The majority of research completed in the area of success and the entrepreneur seems to be examining personal characteristics and how they contribute to the success of the small business owner (Hornaday et. al. 1987)

The results of these studies have led to continued debate as to whether the characteristics of the successful entrepreneur are a result of pyschological or sociological factors, or a combination of factors.

Gartner (1982 p. 1) in a study of 106 business start ups, suggested the following:

...the sample of entrepreneurs and their firms do not seem to differ radically from the population of all individuals and the population of all firms in the United states. We suggest that entrepreneurs and their firms are not unique: no particular characteristic seems to set entrepreneurs as a group apart from the general population of individual and firms (except, of course, for the fact that entrepreneurs start businesses).

There has been more research done on the personal and behavioral characteristics attributed to the entrepreneur in the past twenty years than any other topic 
in this discipline (Hills, Welsch 1978).

One recent paper analyzed 227 studies published in the 1981 through 1986 volumes of Frontiers of

Entrepreneurial Reasearch. Among the findings, the most studied topic was the personal characteristics of the entrepreneur (Hornaday et. al. 1987).

Dunkleberg and cooper (1982) believed their empirical study on entrepreneur typologies to be "the largest and most diverse sample of small business owners studied to date." They studied a random sample of the 1979 membership of the National Federation of Independent Business.

The 1,805 respondents were analyzed to determine a typology with three entrepreneurial categories: 1) growth 2) independent and 3) craftmanship. The three types were found to differ with respect to the amount of their education, their previous functional and supervisory experience, the way in which they became owners, the growth rate of their firms, and the compensation which they enjoyed (Dunkleberg and Cooper 1982).

Mcclelland (1961, 1976) identified the personality characteristics of the entrepreneur as need for achievement, search for self actualization, and risk taker. In attempting to answer the question of why individuals initiate new business ventures, researchers have developed psychological profiles of the entrepreneur. Success in this 
area of study has been limited. The studies have attempted to discover common personality traits possessed by most entrepreneurs. Greenberger and Sexton (1987 p. 52) explained the problems associated with this type of study: "... even if a sufficiently large list of
personality traits could be developed and
thereby account for a reasonable percent of
variance associated with new venture
initiation, the variables would only be
associated with entrepreneurial behavior;
trait theory alone will not explain why
individuals initiate their own ventures." In addition, Greenberger and sexton (1987) pointed out there are two principal methodological problems associated with psychological trait studies. The first is that many studies utilize very small sample sizes and samples chosen for convenience rather than representativeness. Secondly, there may be serious problems about the validity of measures utilized.

one characteristic most often thought to be true about the entrepreneur is that most small business owners are male. In fact most information available about the nature, characteristics, and performance of the small firm and its associated entrepreneur is based on studies conducted amongst predominately, if not exclusively, male business owner/managers (Birley et. al. 1986). Recent available data shows that women are beginning to own and operate their own businesses at a faster rate than their male counterparts.

The Bureau of Census (1982 p. 218) report indicated 
that women represented 51 percent of all sole proprietors. U.S. Small Business Administration The State of Small Business A Report to the President; it was reported that in 19832.8 million sole proprietorships were owned by women, four times the number reported in 1977 (1984).

Hisrich and Brush (1983) estimated that in the U.S. the number of female-run businesses probably exceeded three million and that they form the fastest growing group of entrepreneurs.

of the several factors contributing to the unprecedented growth of women-owned business, four have been identified by Olivas (1987 p. 30):

1. as wage and salary workers women have acquired skills and experience that can be translated into entrepreneurship.

2. achievement in higher education places more women in non-traditional occupations.

3. support by parents and male co-workers in the pursuit of careers in business.

4. the ease of entry in the SIC classification "miscellaneous and other services" because of low capital requirements.

In addition, Hisrich and Brush found the typical

female entreprenuer to be first born, from a middle or upper class family, and the daughter of a self-employed father.

In summary, the only generalization to be drawn

from the data reviewed on the characteristics of the entrepreneur is that there is a lack of concensus on who and what the entrepreneur is. Evidently, there is either a lack 
of conclusive scientific evidence of characteristics that are common to all entrepreneurs, or it may be that there are no common characteristics.

Gordon Baty in his book Entrepreneurship in the

Eighties addresses this concern:

While it may be interesting to know this sort of average or modal information, much of it totally misses the point of entrepreneurship: the diversity (or if you will, statistical dispersion of variance) of traits that have historically characterized successful

entrepreneurs. If you don't seem to fit neatly into the traits profile, you may take comfort from the fact that Edison, Ford, Land, and most of our other entrepreneurial geniuses probably wouldn't have either.

\section{SMALL BUSINESS - SUCCESS OR FAILURE}

The U.S. Department of the Treasury Internal

Revenue Service statistics of Income show that the total number of active businesses increased from 1,965,000 in 1965 to $8,169,000$ in 1980 . In 1980 more than 2,200 new businesses started each day compared to 350 per day in 1950 . A great deal of controversy exists over what constitutes a small business. The following passage taken from The State of Small Business: A Report of The President (U.S. Small Business Administration 1984) made reference to this issue:

To count the number of businesses, it is necessary to make two distinctions: between businesses with and without employees, and between businesses with more or less than $\$ 10,000$ in gross sales in a recent year. This procedure required defining small firms in a consistent way: 
firms with fewer than 100 employees are considered small businesses.

In your Business and the Small Business

Administration (1980) the SBA describes a small business as "one that is individually owned and operated and that is not dominant in its field of operation."

For its loan program the SBA has established criteria for the categorization of small business by size and industry. Of the 14 million businesses in this country, 998 are considered to be "small businesses" (U.S. Small Business Administration, Business Loans from the SBA 1981). Although, 12 to 15 percent of all small businesses go on to become big business, 40 percent of all new businesses fail during their first year; and one out of two businesses does not last four years (Steward and Boyd 1985).

A great deal of conflict exists over not only what a small business is but also over the failure rate. Statistics which list the failure rate of small businesses are often inflated as they do not take into account those businesses which may have changed types of legal ownership, or have changed business names, or those which may have dissolved by choice. This also explains the huge discrepancy in numbers of business failures between various studies.

In 1981 when President Reagan appeared before a joint session of Congress, he stated that in the six months 
since his election the economy had progressively worsened. one statistic he used as support was that 6,000 small businesses -- a major employer of Americans workers-- had failed in the preceeding six months (Russell 1982). The President did not elaborate on the reasons for this staggering statistic, but many researchers have.

\section{The Program for Acquiring competence in}

Entrepreneurship (Ashmore, Pritz, 1983) listed fourteen reasons for small business failure. Among these were: (a) lack of experience (b) lack of capital (c) poor location. Chilton and Weidenbaum (1982) pointed out that adverse environmental conditions and ineffective management decisions can have devastating effects on new venture success.

The National Task Force on Education and Training for Minority Business Enterprises (1974) offered the following conclusions:

The primary cause of business failure is lack of management and business skills

There is a chronic shortage of trained talent to meet present and future needs for owners and managers

Entrepreneurship as a career opportunity has been ignored by the educational system

There is a wide range of entrepreneurship resources at the national, state and local levels

Small business education and training programs must become an integral part of a national education strategy 
According to Timmons, Smollen and Dinges in their book New Venture creation, the following criteria enhances the entreprenuers' chance for success:

1. A capable lead entreprenuer who has determined his/her entrepreneurial strengths and shortcomings and has established a balanced and compatible entrepreneurial team

2. A feasible business idea

3. Appropriate financing

As with all aspects of entrepreneurship, debate exists over the definition of success. Dr. Howard Aldrich (1987) offers the following: "success can first be defined as founding a new business. The second is to define success as establishing a profitable business."

\section{SUMMARY}

A study commissioned by the Small Business Administration found that small businesses fail at the rate of 400,000 a year. This statistic coupled with the 50,000 new businesses that are created each month has made an impact on the nation and more specifically on educational institutions (Zelinko 1983).

It is hoped that a reduction in the failure rate of small business may be achieved through education of not only those entrepreneurs at risk of failure, but also those prospective entrepreneurs involved in pre-venture start up. The need for continued research in the area of 
entrepreneurship education is apparent in order for educators to go about the preparation of students for careers in entrepreneurship.

The difficulty lies in that there has been little research completed in which instructional topics prepare the prospective entrepreneur for small business success.

The review of literature proved many things; 1) that a definition of entrepreneur that is widely accepted and universally used does not exist, 2) that research focuses on personality and socio-demographic characteristics, and 3) that the research has not been able to provide any conclusive evidence as to what determines small business success.

Two common themes did emerge from the review; 1) that although there is a lack of agreement on most of the topics studied, entrepreneurship is essential to the continued national economic growth, and 2) that entrepreneurship education may enhance small business start-up and future success.

Sexton (1982 p. 384) when asked "can

entrepreneurship be taught?" responded:

There is still considerable discussion as to whether entrepreneurial tendencies are hereditary or environmental and therefore subject to learning and application. There seems to be general agreement among researchers that although certain characteristics may be inborn or acquired early in life, one can be taught techniques and methodologies that significantly enhance the probability of 
initiating and successfully completing a new venture. Further studies in the area are needed to resolve the issue so that serious researchers need not expend effort justifying their research. 
CHAPTER III

\section{METHODS AND PROCEDURES}

\section{INSTRUMENT DESIGN}

Data for this descriptive research study were gathered by questionnaire. The survey technique enabled the investigation to elicit opinions on a number of selected topics from the subjects. In addition the demographic data provided by the subjects allowed for comparisons between various sub-groups.

The instrument was designed on the style of other existing questionnaires, mainly three sources. A 12-page survey of entrepreneurial activities was obtained from the oregon state Department of Education. It was determined that the checklist originated from the Illinois state Department of Education.

The Illinois state Department of Education, Department of Adult, Vocational, and Technical Education, had developed the 12-page checklist which contained eleven duty areas of small business knowledge with sub-topics of specific entrepreneurial activities, which were ranked from "critical" to "not done." The checklist was used to develop an entrepreneurship education guide entitled "crosswalk of the Education for Employment Entrepreneurship Education 
Guide." The checklist, although comprehensive, was too cumbersome for the purpose of this study.

The second source was from a doctoral dissertation done by Nona Denton at Southern Illinois University, on the "Perceptions by Educators on Entrepreneurship and Entrepreneurship Education." Her study utilized a brief 16 question checklist on knowledge needed by the entrepreneur for small business success.

The final source used was the Program for Acquiring Competence in Entrepreneurship (PACE). PACE was cited frequently in the "Crosswalk of the Education for Employment Entrepreneurship Guide."

PACE level three, which was the basis of the instrument is currently being used by both secondary and post-secondary schools nationwide. The 18 topics and subtopics presented in PACE were similar to those topics or "duty areas" used in the Illinois study and also those used in the Denton study. Since the purpose of this study was to provide supporting data for entrepreneurship education curriculum development, the PACE student Competency Checklist provided a logical and sequential order to the information contained in the questionnaire.

In an effort to create an instrument that would not intimidate the respondents by its length and that would be of value not only to this study but to future studies, three of the eighteen topics were deleted. since the subjects in 
this study were currently involved in new venture start up the following parts: 1)Understanding the Nature of small Business and 2) Determining Your Potential As An Entrepreneur were omitted. Furthermore, the sub-topics contained under the topic "Managing The Business" were similar to others presented in the PACE curriculum, so this was also deleted. The questionnaire was developed using the Likert scaling technique, with the following five responses for each statement; not important, little importance, important, very important, uncertain.

The questionnaire was divided into sixteen

sections which include Developing A Business Plan, Obtaining Technical Assistance, Choosing the Form of Legal Ownership, Financing the Business, Planning the Marketing strategy, Locating the Business, Dealing With Legal Issues, Complying With Government Regulations, Managing Human Resources, Promoting the Business, Managing Sales Effort, Keeping the Business Records, Managing Finances, Managing Customer Credit and collection, Protecting the Business, and other. Under each section were one to six statements which identified specific entrepreneurial activities. Each of the statements are shown in the sample questionnaire listed in Appendix C.

The survey instrument was reviewed and critiqued for content validity by Dr. Leonard Robertson, advisor and instructor at Portland State University, Fay Jensen, 
Marketing specialist for the oregon state Department of Education; and Alan Zell, entrepreneur and business consultant.

The following revisions were made to the original questionnaire:

1. The addition of "other" as an opportunity for the respondents to identify additional areas of concern.

2. The layout was altered in order to facilitate the completion of the questionnaire.

3. Key words in the statements were changed so that all would be in the same tense.

In addition to the questionnaire a demographic sheet (Appendix B) was added to develop a profile of the respondents, to provide a basis for comparison of the respondents answers with previous research, and for use in follow-up studies.

Information gleaned from the literature review was incorporated into the demographic sheet. For example, questions related to the respondents' educational level, sex, age, race, and family background of entrepreneurial ventures had been shown to be important factors in new venture start-up and warranted further investigation.

A pilot study was conducted using the small Business Ownership class at Wilson High School in Portland, oregon. This class was selected for the pilot because it was currently using the PACE level three materials. The instructor of the course distributed the 
instrument to her students without any oral instructions. The purpose of the pilot study was to determine what elements of the instrument if any were in need of refinement and clarification. It was determined that the questionnaire was useable without any additional refinement.

\section{SELECTION OF THE SUBJECTS}

Since the problem of the study was to obtain the opinions of prospective entrepreneurs involved in preventure training the most logical source for subjects was through the courses offered by the local Small Business Development Centers.

The sample selected included those students enrolled in the starting Your Own Business classes offered by the Portland Small Business Development Center, and the two Green-house programs offered through the Clackamas Small Business Development Center. Because the enrollment in the Starting Your Own Business classes was extremely small winter term the classes were cancelled. This resulted in the delay of the distribution of the questionnaires until spring term.

These two centers were selected because they serve not only the city of Portland, but also its suburbs and its surrounding rural communities. Financial and logistical constraints resulted in the exclusion of all other SBDC's in oregon.

Enrollment in the SBDC courses are sporadic and 
often result in cancellations due to lack of enrollment. Had this been a longitudinal study over a period of an entire year it would have been possible to create a larger sample, but due to time limitations and financial obligations this was impossible.

\section{METHODOLOGY}

A total of 89 questionnaires were distributed to all enrollees in the classes. The two instructors involved in the Clackamas SBCD Green-house programs agreed only to distribute the questionnaires to their 20 students each, during the first class meeting. As a result, a selfaddressed stamped envelope was included with each questionnaire along with a cover letter explaining the nature of the study.

There was no opportunity to conduct a follow-up of the Clackamas SBDC students since the names of the students enrolled in the program were kept confidential.

The two instructors who taught the starting your Business courses through the Portland SBDC, agreed to allow the 49 students who attended the first class meeting to complete the questionnaire during class. Their cooperation in not only the distribution but also the collection of the completed surveys improved the return rate of the responses, as shown in Table $I$. 


\section{DATA ANALYSIS}

Data from the study were analyzed using descriptive and inferential statistics. The statistical Package for the Social Sciences (SPSSX) was used to prepare frequencies of the data and to run the tests of significance.

Analysis of variance was used to test for significance where the independent variable was multivariate. A t-test was used where the independent variable was bi-variate. In all tests of significance, the dependent variable was the mean scores of the topics on the questionnaire.

For the purpose of analyzing some of the data, the assumption was made that subjects who had either previously owned a small business or who had parents who had owned one would be better judges of the importance of the topics evaluated than those without such backgrounds.

\section{SUMMARY}

The sample selected included 89 students enrolled in the starting Your Own Business classes offered by the Small Business Development Centers. There was no opportunity to conduct a follow-up since the names of the students were kept confidential.

Data for this descriptive research study were gathered by questionnaire and a demographic sheet. The questionnaire was developed using the Likert scaling 
technique with the following five responses for each

statement; not important, little importance, important, very important, uncertain.

The demographic sheet contained questions related to the respondents' educational level, sex, age race and family background of entrepreneurial ventures, which had been shown to be important factors in new venture start-up. 
CHAPTER IV

\section{FINDINGS}

A total of 53 of the 89 prospective entrepreneurs surveyed responded with completed questionnaires, which yielded a $60 \%$ response rate.

\section{TABLE I}

SURVEY RESPONSE RATE

SBDC CENTER

Clackamas

Portland

TOTAL \# DISTRIBUTED

40

49

89
\# RETURNED

4

49

53
RATE

$10 \%$

$100 \%$

$60 \%$

Although the number of subjects in the study was small, 53, the response rate of $60 \%$ was good, compared to many direct mail surveys in which a $20 \%$ return is considered average. Data collected for this study were analyzed by descriptive and inferential statistics. Each response on the questionnaire was coded and recorded on a floppy disk for computer assisted analysis using sPSS. Null hypotheses were rejected when statistical significance was $p>=.05$.

The findings of the data are summarized in the following sections. 


\section{PRESENTATION OF DEMOGRAPHIC DATA}

The demographic information provided a profile of the prospective entrepreneurs surveyed. In addition, it provided an opportunity to determine whether differences existed among the various sub-groups on the mean scores of their questionnaire responses.

of the demographic data gathered from this study the following information contributed to the development of a profile of the sample used in the study. None of the variables educational level, sex, and marital status shown to have significant differences on the group mean scores of their questionnaire responses.

The majority of the respondents 27 (50.9\%) reported that they were married, $16(30.2 \%)$ were single, and 7 (13.2\%) were divorced. Thirty-one (58.5\%) of the prospective entrepreneurs indicated that they were females and 21 (39.6\%) reported that they were males. The majority of respondents 38 (71.9\%) were between the ages of 26-45 years of age as shown in Table II. 
TABLE II

AGE OF RESPONDENTS

$\underline{\mathrm{AGE}}$

UNDER 20

21-25

26-30

$31-35$

$36-40$

$41-45$

$46-50$

51-55

OVER 56
PERCENT

1.9

7.5

17.0

18.9

17.0

18.9

7.5

3.8

7.5

The majority of respondents $22(41.5 \%)$ reported a high school diploma as their highest educational achievement, the percentage of the educational level attained by the respondents is illustrated in Table III.

TABLE III

EDUCATIONAL LEVEL ATTAINED BY RESPONDENTS

EDUCATIONAL LEVEL

High School Diploma

Associates Degree

B.S.

Graduate school

Doctorate

other
PERCENTAGE

41.5

15.1

17.0

18.9

1.9

5.7

The following three demographic categories; race, prior business ownership, and family entrepreneurial background provided the only statistically significant differences on the mean scores of their questionnaire responses. The differences found will be addressed in the section Presentation of the Questionnaire Data. 
In regards to the race of the respondents, 49 (92.5\%) indicated they are caucasian, 1 (1.9\%) was reported as hispanic, and $3(5.7 \%)$ prospective entrepreneurs indicated that they were Asian.

\section{PRESENTATION OF THE QUESTIONAIRE DATA}

The questionnaire was divided into 16 sections of business knowledge with 2-6 sub-topics listing specific activities needed for small business success. There were a total of 47 sub-topics. Appendix D illustrates the frequency of responses from the subjects.

Because the questionnaire was developed using the Likert scaling technique the following values were assigned to assist in the statistical analysis; not important $=1$, little importance $=2$, important $=3$, very important $=4$, uncertain=5. The value of 5 for the uncertain response was ignored when the mean scores were computed so that the mean scores would not be inflated.

on the level of the specific activities the prospective entrepreneurs responded most frequently with "very important" to (a) developing a financial plan (83\%), (b) determining the necessary financing (79.2\%), and (c) obtaing business insurance (69.8\%).

The respondents most often answered that the following were of "little importance," (a) preparation of advertising calendar (24.9\%), (b) conduct market survey 
$(22.7 \%),($ (c) selection of micro-computer application for financial management $(24.5 \%)$, (d) select promotional product merchandise or service $(20.2 \%),(e)$ selection of advertising agency (35.9\%), (f) preparation of a credit promotional plan (31.3\%). These figures take into account those prospective entrepreneurs who responded "not important or "little importance."

The questionnaire section "other" received only one response. One subject answered that "all the topics listed were equally important."

Table IV provides a ranking of the mean scores of the sections. The mean scores reported in Table IV represent the mean for all sub-topics contained within the sections listed. This information will be used in the development of entrepreneurship education curriculum, as the findings show which topics are of most importance to small business success as perceived by prospective entrepreneurs. Furthermore, since the basis for the questionnaire was the PACE competency checklist we can infer on the basis of the findings that all the topics are important to entrepreneurial training. 
TABLE IV

RANKING OF THE MEAN SCORES OF THE SECTIONS ACROSS RESPONSE

Complying with Government regulations Developing A Business Plan

Financing The Business

Choosing The Form of Legal ownership

Protecting The Business

obtaining Technical Assistance

Keeping The Business Records

Managing Finances

Dealing with Legal Issues

3.651

3.622

$3.53 \quad 3.5$

$3.53 \quad 3.5$

3.515

$3.48 \quad 6.5$

$3.48 \quad 6.5$

$3.40 \quad 8.5$

$3.40 \quad 8.5$

Locating The Business

Planning The Marketing strategy

3.3610

Sales

Managing Customer credit And collection

Promoting The Business

3.2411 .5

$3.24 \quad 11.5$

$3.20 \quad 13$

$3.15 \quad 14$

Managing The Human Resources

$3.10 \quad 15$

$\mathrm{n}=53$

With the mean score of the topics as the dependent variable analysis of variance was conducted using four different multi-variate sub-groups, (a) race, (b) marital status, (c) educational level achieved, and (d) age. A ttest was completed on the following bi-variate sub-groups (a) sex, (b) prior small business ownership, and (c) family entrepreneurial background.

There were no significant differences found between the mean scores of the male and female groups, those groups with various educational backgrounds.

significant differences were found for the variable "race." These differences pertained to the importance of (a) developing an advertising plan $F(2,49)=9.53, p=.000$, 
(b) location of the business $F(2,48)=6.38, p=.003$, and (c) developing the sales plan $F(2,49)=6.13, p=.004$.

Due to the small sample size of ethnic minorities in the study, the effects of the factor "race" should be regarded with caution. It should not be inferred that races differ in response to the knowledge needed for small business success. Minority participation in the survey accounted for only 4 out of the 53 responses received.

The small number of minorities involved in this study may be explained in part by the availablity of an alternative Small Business Management program, which is offered through Portland Community college by the oregon Association of Minority Entrepreneurs. Since this program is offered as an alternative to the SBDC starting Your own Business program and deals with specific issues the minority entrepreneur may encounter the number of minorities in this study was diminished.

Significant differences in subjective importance of the topics were found between the group of respondents who had previously owned their own small business and those who had not. Responses on the Managing Finances question yielded a value of $\mathrm{p}=.029$. People who had owned their own businesses considered the topics more important.

Furthermore, a total of 24 (45\%) respondents reported that they had come from a family where either one or both of their parents had been entrepreneurs. 
significant difference existed on both the (a) Developing an Advertising Plan $\mathrm{p}=.017$, and (b) Managing Finances $\mathrm{p}=.025$. The significant differences discussed above are illustrated in Table $\mathrm{v}$.

As shown in Table $\mathrm{V}$ the mean scores of the respondents who had a background of family entrepreneurial ventures felt the topics "Advertising" and "Financial Management" to be more important.

\section{TABLE V}

SIGNIFICANT DIFFERENCES IN VARIABLE OF PERCEIVED IMPORTANCE BETWEEN SUB-GROUPS

Group 1= Prior Small Business Ownership Group 2= No Prior Small Business Ownership $\mathrm{n}=13$ TOPIC MEAN sd df $t$ $n=40$ TOPIC GP1 GP2 GP1 GP2

$\begin{array}{llllllll}\text { Financial Mgmt. } & 3.75 & 3.39 & .412 & .635 & 50 & 2.29 & .029\end{array}$

$\begin{array}{ll}\text { Group 1=Family Entreprenuerial Background } & \mathrm{n}=24 \\ \text { Group 2=No Family Entrepreneurs } & \mathrm{n}=29\end{array}$ TOPIC

MEAN

sd

df $t$ $\mathrm{p}$ $\begin{array}{lrrrrrrr} & \text { GP1 } & \text { GP2 } & \text { GP1 } & \text { GP2 } & & & \\ \text { Advertising } & 3.39 & 3.01 & .412 & .691 & 50 & 2.49 & .017 \\ \text { Financial Mgmt. } 3.68 & 3.31 & .569 & .587 & 50 & 2.31 & .025\end{array}$ SUMMARY

With the importance of the topics as the dependent variable, an analysis of variancs was conducted on four different multi-variate sub-groups: a) race, b) age, c) marital status, and d) educational level. 
significant differences were found for the factor "race". Extrapolation with other studies is not recommended as the sample size of minorities was small.

The respondents who indicated prior small business ownership felt the topic "Managing Finances" was more important to small business success, than those who had not owned their own business.

The subjects who came from a family where at least one parent was an entrepreneur displayed a significant difference on two sections; a) Managing Finances and b) Advertising Plans. Again those repondents with a background of entrepreneurial ventures felt the topics were more important to small business success than those who had not come from a background of entrepreneurs.

A ranking of the mean scores of the questionnaire responses of all respondents, established that all of the topics listed are of importance to the development of entrepreneurship education curriculum. 


\section{CHAPTER V}

\section{CONCLUSIONS}

The study of entrepreneurship for curriculum development was listed as the major purpose for this study. The findings of this study will be used to assist in the development and evaluation of the new Small Business Ownership class at Wilson High School for the 1990-91 school year. Since the curriculum development using the Work Force 2000 grant money will begin in June 1990, this study has provided timely and worthwhile findings. Work Force 2000 is the plan developed by the oregon state Department of Education of how Oregon will educate and train a viable work force for the year 2000 .

Furthermore because the oregon state Department of Education office of Vocational/Technical Education encourages the inclusion of entrepreneurship in all secondary vocational courses the findings will provide a basis for additional curriculum development. Currently, only two secondary entrepreneurship education programs have been identified in Oregon (Robertson 1990). Faye Jensen, Marketing specialist for the state Department of Education, has identified a number of new entrepreneurship courses that are in the development stages. 
Although the respondents varied in age, educational level, and sex their responses appear quite consistent. Very few items were marked "not important." The majority of the responses were reported as either "important" or "very important."

of the data gathered and analyzed some interesting findings occurred within the demographic data. of those findings that supported prior research efforts, the first was that $59.5 \%$ of the respondents were female compared to the $39.6 \%$ that were male. This comparison figure supports prior research on the increasing number of women entrepreneurs. In fact, the $59.5 \%$ women entrepreneurs represented by this survey exceeds the $51 \%$ women entrepreneurs identified by the U.S. Small Business Administration (1984).

The number of minority respondents involved in this study totaled less than one percent. Although an effort has been made to explain the small numbers, the 1972 Bureau of Census similarly reported that minority entrepreneurs accounted for less than $1 \%$ of all U.S. firms in 1977. of the sub-groups which were analyzed for differences between their mean scores on responses, the groups which were compared on family entrepreneurial history provided the greatest differences and most useful information for curriculum development. Regarding family history, Shapero and sokol also (1982) found, parents play 
an important role in developing the desirability and credibility of entrepreneurial ventures. Furthermore, results from a number of studies (Scanlan 1980, Petrof 1980, and Shapero 1980) put the average of entrepreneurs who were from families where at least one parent was an entrepreneur at 50\%. The average of prospective entrepreneurs involved in this study, who were from families where at least one parent was an entrepreneur was $45 \%$. We could infer that the significant differences found in their opinion on the importance of advertising plans and managing finances suggests that a greater instructional emphasis be placed on these topics with those prospective entrepreneurs who do not come from a family background of entrepreneurs.

A recent survey of the National Federation of Independent Business members who had recently started their own businesses, found that at least $92 \%$ had at least a high school diploma (Vandrey 1987). When the percentages of the respondents who had achieved higher levels of education were included with the respondents who reported at least a high school diploma it brought the average to $94.4 \%$ prospective entrepreneurs who had attained a high school diploma.

The greatest number of respondents 38 (71.9\%) were between the ages of 26-45. This figure supports prior research which states that most entrepreneurial ventures of substantial scope are undertaken after the age of 25 (Price 1984). Furthermore the peak age range for new venture start 
up is between 30-40 years of age.

Although the greatest percentage of entrepreneurs begin small business ventures after the age of 25 , it is important to introduce entrepreneurship as a viable career option at the secondary level. As Vesper (1984) showed over 245 schools of higher education now offer programs in entrepreneurship education. Important to adapt these findings for use at the secondary level.

Although the sample selected for this study was not intended to be reprensentative of all prospective entrepreneurs in the United States, the demographic profile developed on the subjects closely matches the profile of a majority of prior research on entrepreneurs as shown in Table VI.

Table VI provides a comparison between the demographic percentages found in this study and the percentages found in prior research efforts.

\section{TABLE VI}

PERCENTAGE

CURRENT STUDY

DEMOGRAPHIC GROUP

Sex - Female

High School Diploma

Family Entrepreneur

Prior Business Owner 25\%
PERCENTAGE

PRIOR

51\% Bureau of Census

$92 \%$ Dinkleburg

$50 \%$ Shapero

$27 \%$ HOY

ACCEPTANCE OF NULL HYPOTHESES

The results of this study demonstrated that the results are consistent across sub-groups of age, educational 
level, marital status, and sex. Significant differences were found on individual sub-topics between the groups differing on whether there was Prior Small Business Ownership or not, and also between the groups differing Family Entrepreneurial Background.

since the number of minorities who participated in the survey was small it can be inferred that the differences found were significant, but the results should not be generalized to other studies.

RECOMMENDATIONS FOR FURTHER STUDY

The following are recommendation to those who may be interested in replicating this study. There exists a need for further research and possible improvements in the methodology used in this study. Four specific areas where improvements are given include the addition of a control group of prospective entrepreneurs not involved in preventure training. This recommendation would be difficult to achieve as prospective entrepreneurs are people who are involved in pre-venture start-up, and who do not belong to any of the professional organizations available to the entrepreneur. This explain the reason for not including a control group in this study. The addition of the OAME students would increase the number of minority subjects in the study.

The addition of secondary students identified as 
prospective entrepreneurs would assist in the adaptation of findings to secondary curriculum development. At this time it would be difficult to add a group of teen-age prospective entrepreneurs since only two entrepreneurship programs exist in oregon. Furthermore, the pilot study used for the study was a secondary entrepreneurship class. The responses on the questionnaires received from the students did not differ greatly from those of their adult counterparts. This suggests that inclusion of a group of secondary students to the study may not show any significant differences.

Finally, the addition of a group of entrepreneurs who had successfully owned and operated their own business for at least five years would have shown if any differences existed between what prospective entrepreneurs perceive to be important and what entrepreneurs found to be important. Addition of this group was impossible for the study as the names of the students are confidential. A future study would be possible with a group of successful entrepreneurs, as almost 408 of the respondents included their names and addresses.

\section{SUMMARY}

Data for this study were gathered by questionaire using those prospective entrepreneurs enrolled in the SBDC Starting Your Own Business courses.

The data were analyzed to determine what 
instructional topics should be included in entrepreneurship education curriculum as perceived by the respondents. The results of this study demonstrate that the results are consistent across sub-groups of age, educational level, sex, and marital status. Significant differences were found on individual sub-topics between the groups differing on whether there was Prior Small Business Ownership or not, and also between the groups differing Family Entrepreneurial Background.

The findings of the mean scores of the respondents suggest that all the topics listed on the questionnaire are equally important to future small business success and should be included in entrepreneurship education curriculum. 


\section{REFERENCES}

Aldrich, Howard Dr., Rosen, B., Woodward, W. (1987). "Impact of Social Networks on Business Foundings and Profit: A Longitudinal Study". University of North Carolina.

Ashmore, M.C., Pritz S.G. (1983). A Program for Acquiring Competence in Entrepreneurship (PACE). Ohio state University, The National center for Research in Vocational Education.

Bailey, John, E. (1985). Learning Styles of Succesful Entrepreneurs. Chisholm Institute of Technology.

Birley, Sue, Moss, Caroline, Saunders, Peter. (1986) "The differences between small firms started by male and female entrepreneurs who attended small business courses". Cranfield School of Management.

Cantillion, R. "Essai sur la Nature du Commun en General. Institut National de Etudes Demographics, 1952.

Chrisman, J.J., Hoy, Frank, Fobinson, R.B., (1984). "New Venture Development: The Costs and Benefits of Public Sector Assistance". University of South Carolina.

Collins, O.F., Moore, D.G., The Organization Makers: A Behavioural study of Independent Entrepreneurs, New York: Appleton-Century-Crofts, 1970.

Denton, Nona (1985). "Perceptiongs of Entrepreneurs and Secondary Vocational Educators on Selected Aspects of Entrepreneurship and Entrepreneurship Education." Doctoral Dissertation, Southern Illinois University.

Dinkleberg, W.C., Cooper, A.C., Entrepreneurial Typologies: An Empirical study. Purdue University.

Gartner, William, B. (1982). "Problems in Business Start-up: The Relationship Among Entrepreneurial skills and Problem Identification for Different Types of New Ventures." University of Virginia.

Greenberger, David, B., Sexton, Donald, L. , (1985,1987). Leadership and Entrepreneurship: New Directions for Ventures Initiation and Success. Ohio state University. 
Greenwood, K. , Bice, G.R., LaForge, R.W., wimberley, D.. (1984) Resources for Entrepreneurship Education. (Contract No. 300- 820-071). Washington D.C.: U.S. Dept. of Education \& U.S. Dept. of Commerce.

Hills, G.E., Welsh, Harold (1978). Entrepreneurship and Student Independence, Characteristics and Experiences, University of Illinois.

Hornaday, J.A., Churchill, N.C.. Current Trends in Entrepreneurial Research. Babson College, 1987.

Kent, C.A., (1984). The Environment for Entrepreneurship. Lexington, MA: Lexington Books, D.C. Heath and Company.

Knight, R.. "Entrepreneurship in Canada", Journal of Small Business-Canada, vol.1, No. 1 (1983). pp. 9-14.

Mcclelland, D. $(1961,1976)$ The Achieving Society. 1st ed. D. Van Nostrong Co., Princeton N.J., 1961.

National Task Force on Education and Training for Minority Business Enterprise, "Task Force Report". Washington D.C., January 1974 .

Olivas, Louis. "Women Owned Business: A Growing Trend", Business Education Forum, April 1987. pp. 30-32.

Perrin, L.W. (1983). SBA's Educational Activities: Proceedings of the First Annual National Entrepreneurship Education Forum. No page. Columbus: The ohio state University, The National center for Research in Vocational Education.

Porter, Sylvia. Sylvia Porters Personal Finance Magazine, "Start and Succeed in Your Own Business". May 1986, pp. $31-33$.

Powers, Thomas L.. "Small Business Instruction: A Case for Specifics." Business Education Forum. April 1982, pp.3031 .

Ross, Novell. "Small Business in the Eighties: A Nationwide Movement for Entrepreneurship Education:, Workplace Education, October 1984. pp.4-6.

Russell, John S., "Entrepreneurship: A High Priority for Business Educators". Business Education Forum, April 1982. p.32.

Schumpter, J.A., A Theory of Economic Development. Oxford University Press, New York. 1934. 
Schwammberger, Elizabeth R."Business Education with the Small Business Owner", Business Education Forum, April 1987. pp. 29-30.

Sexton, D.L. (1982). "Research Needs and Issues in Entrepreneurship"

Timmons, Jeffery, Smollen, L.E., Dingee, A.G., New Venture Creation, Richard D. Irwin Inc., Homewood Ill., 1977, p. 4 .

U.S. Small Business Administration. Business Loans From the S.B.A. (1981) Washington D.C., U.S. Government Printing Office.

U.S. Small Business Administration. Your Business and the Small Business Administration. (1980) Washington D.C., U.S. Government Printing office.

U.S. Small Business Administration. (1985) Washington D.C., U.S. Government Printing office.

U.S. Small Business Administration. The state of Small Business: A Report to the President. (March 1984) Washington D.C., U.S. Government Printing office.

U.S. Department of Treasury, Internal Revenues Service. "Statistics of Income: Business Income Tax Returns Corporation, Income Tax Returns, Partnership Returns, and Sole Proprietorship Returns". Washington D.C. 1981.

Vesper, Karl H. (1985). New Developments in Entrepreneurship Education. University of Washington.

Zelinko, D.E., Zelinko, M. (1983). Entrepreneurship in Vocational Education: A Guide for Program Planning. Ohio State University. 
APPENDIX A

COVER LETTER 


\section{APPENDIX A}

COVER LETTER

TO: $\quad$ SURVEY PARTICIPANTS

RE: COMPLETION OF ENTREPRNEURSHIP QUESTIONNAIRE

DATE: $\quad$ MARCH 16,1990

This letter is a request for your cooperation and participation in a study I am currently conducting in partial fulfillment of my masters degree. I am studying the perceptions of prospective entrepreneurs on the skills they feel to be most crucial to future success.

The information requested on the demographic sheet will be used confidentially to evaluate the various background factors that exist in the start-up of a small business. Your name is optional, it is only

necessary if you are interested in receiving the results of the survey.

The validity of this research effort is dependent upon the completion of all those questionnaires distributed. Please take the time to complete the demographic sheet and the questionnaire and return it to your instructor.

I appreciate your time and cooperation in this matter. Please be assured that the information will be used only to substantiate my research. 
APPENDIX B

DEMOGRAPHIC DATA SHEET 


\section{DEMOGRAPHIC DATA}

For the purpose of this study a small business is defined as having 20 or fewrer employees.

1. Have you ever owned and operated a small business? Yes ___ No

2. Are you male or female? Female Male

3. What is your age? Under 20
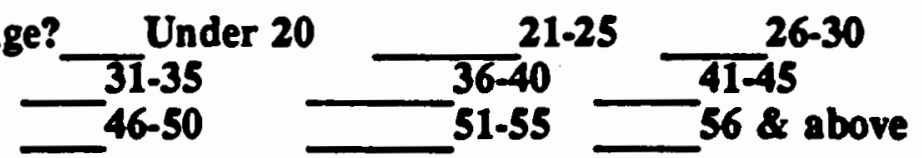

4. What is your marital status? Single Married Divorced Widowed

5. What is the highest degree you have attained?

High School Diploma Attended Graduate School
Associates Degree

B.S. Doctorate Degree

\section{OAttended}
6. Are you Caucasion Asian Native American Hispanic

7. Have either of your parents owned and operated a small business? Mother Father

If you are interested in receiving the results of the completed survey, please complete the following information. Thank you very much for taking the time to assist me in this research.

NAME ADDRESS 
APPENDIX C

QUESTIONNAIRE 
DSTRUCTIONS: Rate each area listed below as you percelve its value to small business sucees by placing an $X$ in the appropriate column.

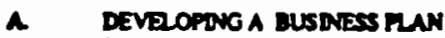

1. Descripoion of ite brimes

2 Matebing plan identification of customen mipplies

3. Orarizition plan

4. Finencid pim

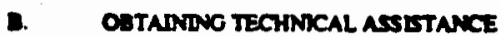

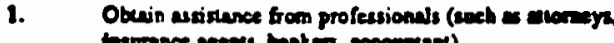

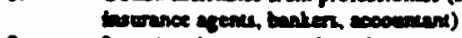

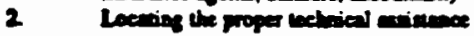

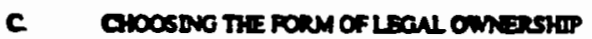

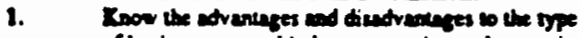

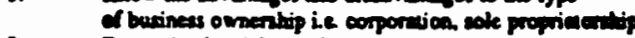

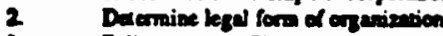

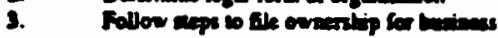

D. RANANG THE MARCTOUE STMTECY -

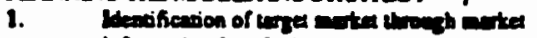

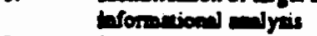

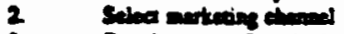
3. Developanes of antudieg as
4. Condea endo nury

E Locatrot the mostess

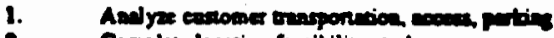
2 Conplet boction faritility andy
3. Selea buines berion

F. Furicong nie tuspiess

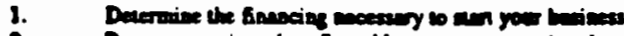

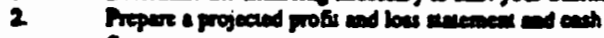
Aow entomen

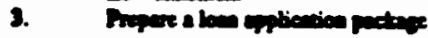

c. PALEO wmy Lan wax

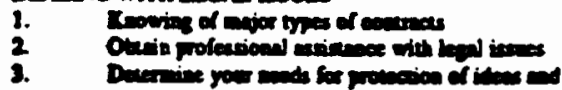
Invios

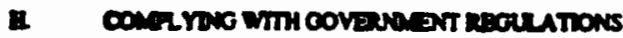

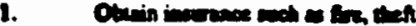

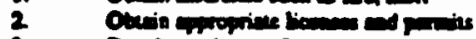

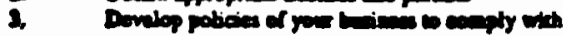

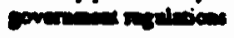
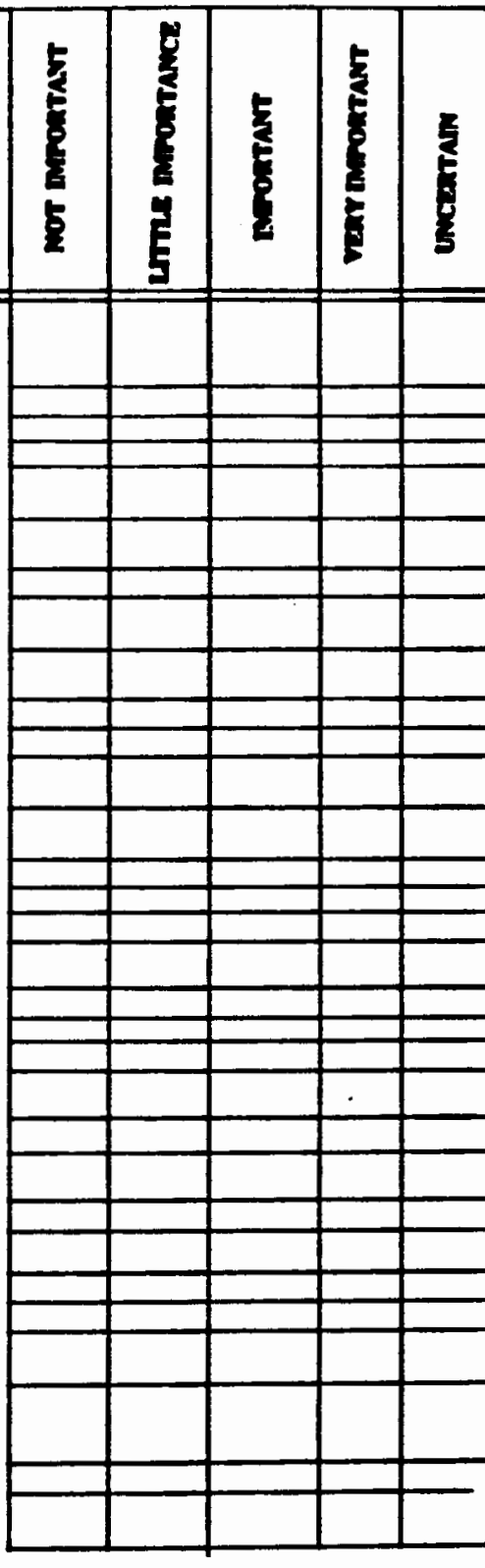
DSTRUCTIONS: Rate each area listed below as you perceive its value to small business success by placing an $X$ in the appropriate column.

1 MANACNGG THE HUMAN RESOURCES

1. Desernine personsel mo

2 Proper deviled job devaripion for ench pridion

3. Develop end apply riving policies and procedures

4. Develop oncline for as enployer evelumion spram

J. PRONOTING tre Busnites

1. Develop promocions objectives

2 Erablish edverisine/promotional bucket

3. Prepere covertisine calendor

4. Selea promosional produc merehandive or varvice

5. Selea utverisine modis

6. Selod utretiving reacy

R MANAONG SNLS DFORT

1. Develop ales plen for you triness

2 Develop unles funcens

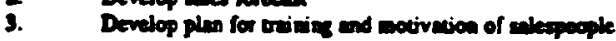

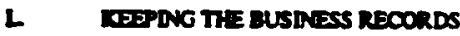

1. Doumine wto will keep boots for your business

2 Mesify types of reocod the yos will we

M MaMGONOFNANCES

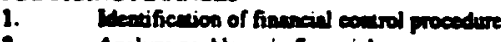

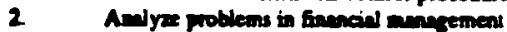

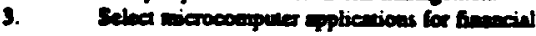

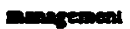

N. MHAONG CUSTOMER CRETT AND COUECTON

1. Develep coutir end collecion paticies

2 Mopere endil prosedion pils

o. MOTECTING THE busniess

1. Prove poticies for your form ind will wap

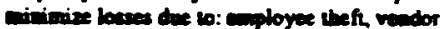

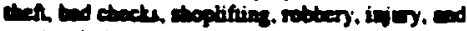
reabibitity

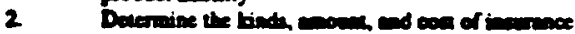
and by yon tom

P. OाIx

1.

2

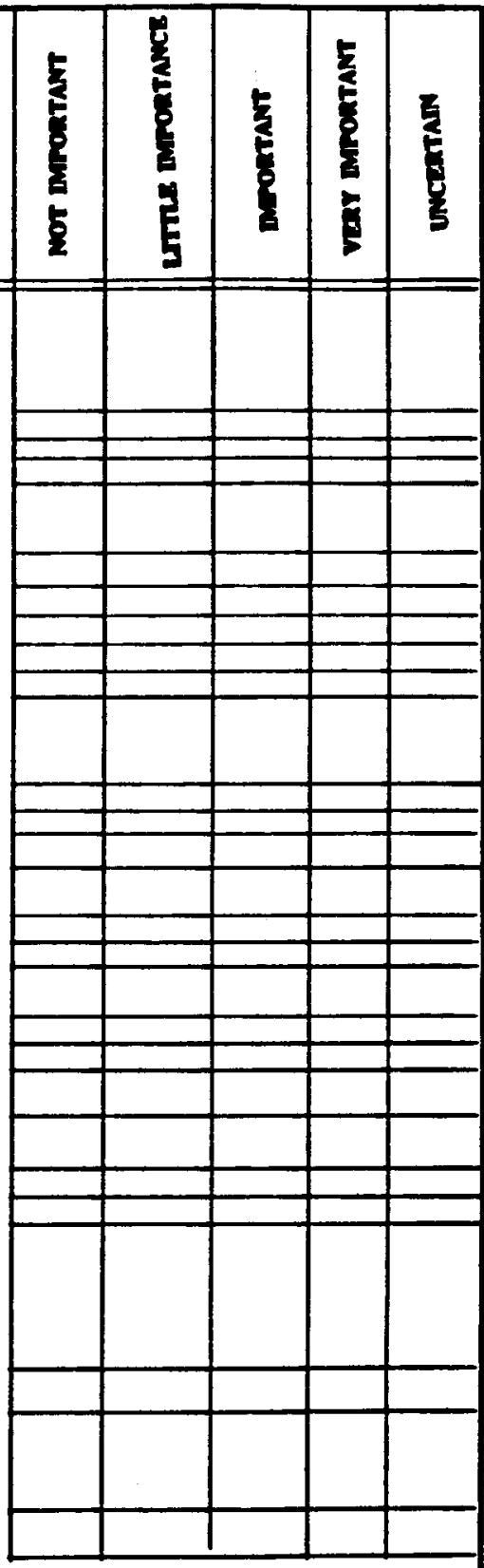


APPENDIX D

FREQUENCY OF RESPONSES 


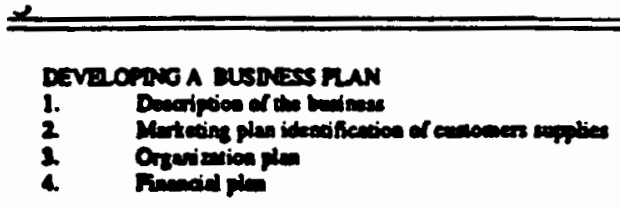

\section{ostalvaic techical asetance}

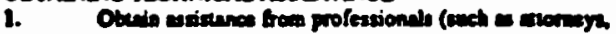

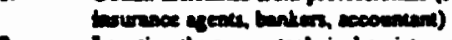

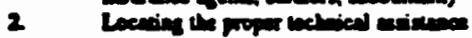

CHOOSNG TIE RONM OF LEAL OWNESHW

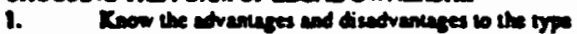

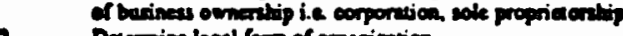

2 Duenies legd form of onferizution

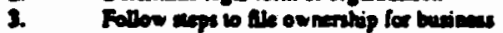

FWNDNO TRE MUNCETUG STRATECY ,

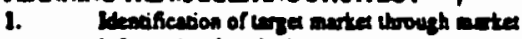

informiniond myis

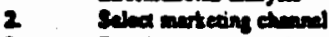

1. Doreloponem of murtetias nix

4. Codea Datra envy

LOCATMO The Dusbixs

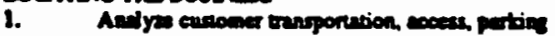

2 Complan becision facedititity endy

3. Salea brimess beriog

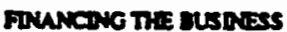

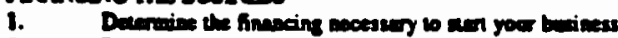

2 Moper a projected profit and loss amennest and each

Dow amedert

3. Pripere a ben apbiendica puctuge

\section{DENDO WTH LECAL ESTES}

1. Enowing of mior bye of abanas

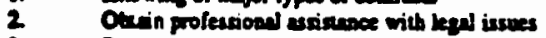

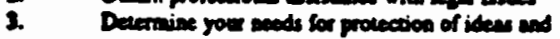
invections

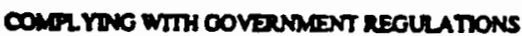
1. Owein issornen weh as firc. then
2 Ovesin sproprinte bionser and parmits

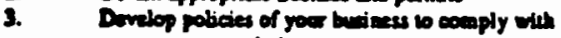 povernmest refulisions

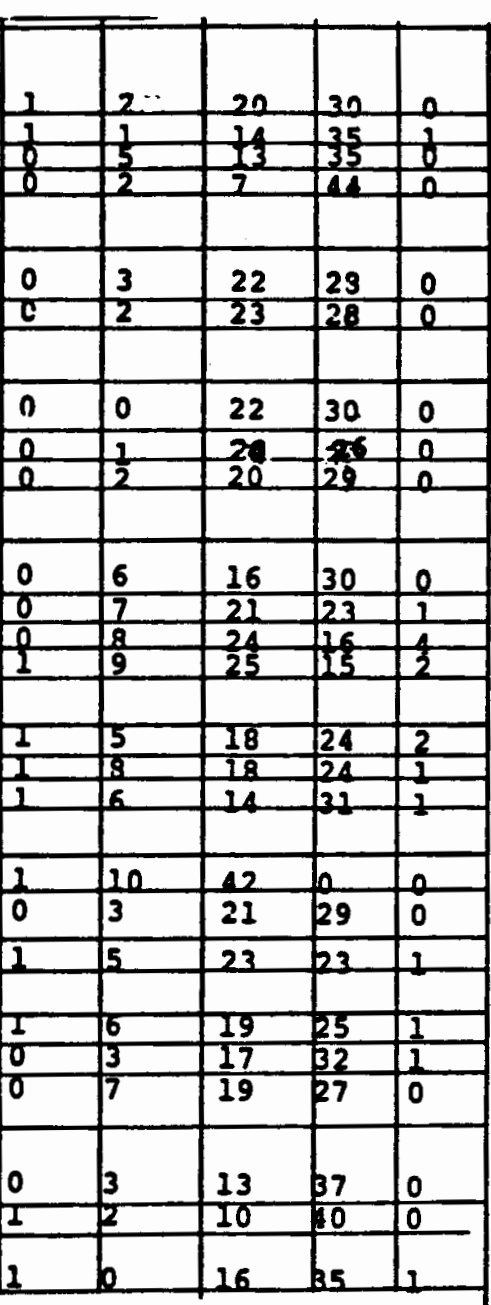


WSTRUCT1ONS: Rate each ares listed below as you perceive its value to small business success by placing an $\mathrm{X}$ in the appropriate column.

1 MANAGDG THE RUMUN RESOURCES

1. Detertion penonsel need

2. Prepere deutiled job decription for each position

3. Develop and epply tivine policies and procedures

4. Develop ocetive for en employer evelumion sysem

J. PROMOTING ThE BUSDIES

1. Develop promotiond otjectives

2. Eseblish etvertising/promotiond budzat

3. Propar etvertising celeads

4. Selea promocionel produa merchandiee or sevice

5. Selea advertising medie

6. Select edvertising epency

K MANAGNG SALES EFORT

1. Develop enles plen for your buriness

2. Develop ales forecens

3. Develop plen for triting and motivetion of selespeople

L TESPRG THE BUSDIESS RECORDS

1. Delernite who will teep books for you business

$2 . \quad$ dexify types of necond the you will use

M Managing finances
1. Mertification of fianscill coutrol procedure
2 Andyex problems in finncisl menugement
3. Selea microcompuer epplications for finuncill menegemert

N. MANAGING CUSTOMER CREDT AND COULECTION

1. Develop redit end collectica policies

2. Propere ardir promotion plen

o. PROTECTING TIE BUSDESS

1. Prepare policies for your firm tha will help miximize losies due to: employee thef, vendor theth bed checks, shoplifting, robbery, injury, and produed tivability

2 Determine the binds, mount, and con of insurance neded by your firm

p. OTHER

1.

2.

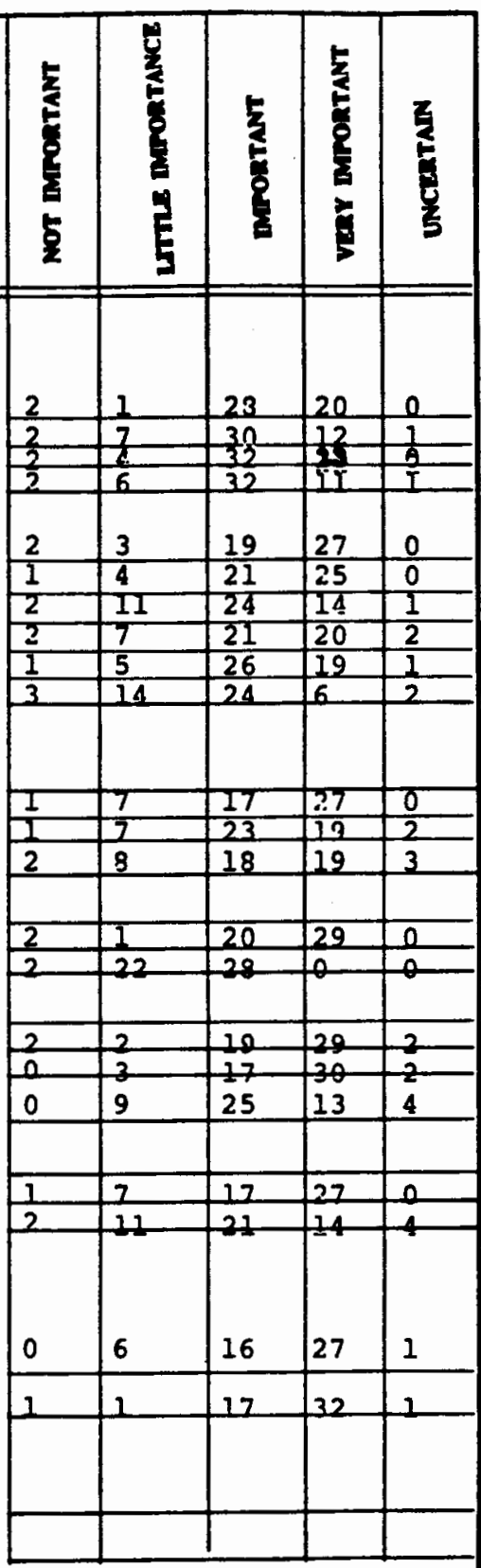

